\title{
THE ROLE OF PROFESSIONAL ATHLETES IN THE DEVELOPMENT OF SPORTS TOURISM IN BOSNIA AND HERZEGOVINA
}

\author{
Sonja Omukić1 \\ Amra Čaušević ${ }^{2}$ \\ Edin Hrelja ${ }^{3}$ \\ Amra Banda ${ }^{4}$
}

\begin{abstract}
The subject of research is the discussion and understanding the role of professional athletes in the development of sports tourism in Bosnia and Herzegovina. The research problem stems from the need for more detailed research of sports tourism in Bosnia and Herzegovina, as well as a detailed research of the role of professional athletes in Bosnia and Herzegovina. A qualitative method was used in the research. The qualitative method was conducted among six experts in the field of sports, in the form of in-depth interviews. The aim of the research is to find out and analyze the views of experts in the field of sports, sports journalism and on the topic of sports tourism and its impact on the image of Bosnia and Herzegovina through the promotion of professional athletes.
\end{abstract}

Keywords: tourism, sports, sports tourism, Bosnia and Herzegovina

\section{INTRODUCTION}

The development of tourism, in most tourist destinations, is marked by the seasonality of tourism, i.e "seasonal movement of tourists as a result of available free time, which in most countries is concentrated in the summer and winter months" (Škorić, 2008). Tourism and sport are two forms of social activities that are interdependent. The correlation between them, as well as the resemblance of their functions, results from the fact that the subjects of both fields appear to be the same. Connection between tourism and sport dates back to the very beginning of their development (Bartoluci, 1995). Although sports tourism has seen rapid growth and development in the last three decades, the link between sport and tourism has only become the subject of research in recent times. The link between tourism and sport in academic circles has remained neglected to this day, while the demand for sports activities has been observed much earlier (Higham \& Hinch, 2001).

Sports tourism is a type of tourism with a special interest, and the basis for distinguishing between different types of tourism with a special interest is "motivation to travel as well as activities during the stay of tourists in a particular tourist destination" (Bartoluci, 1985). The emphasis of such market segmentation by defining the primary tourist motives for which people visit particularly attractive places, is to socialize with

\footnotetext{
${ }^{1}$ Zone manager, Avon cometics d.o.o., Fra Anđela Zvizdovića, 71000 Sarajevo.

${ }^{2}$ Assistant Professor, Department of Geography, Faculty of Science, University of Sarajevo, Zmaja od Bosne 33 - 35, 71000 Sarajevo.

${ }^{3}$ Assistant Professor, Department of Geography, Faculty of Science, University of Sarajevo, Zmaja od Bosne 33 - 35, 71000 Sarajevo.

${ }^{4}$ Senior Teaching Assistant, Department of Geography, Faculty of Science, University of Sarajevo, Zmaja od Bosne 33 - 35, 71000 Sarajevo.
} 
tourists of a similar lifestyle and meet their specific needs (Kesar, 2007). In this sense, "tourism, where sport is the main reason for traveling and staying in a certain destination, is called sports tourism" (Bartoluci, Škorić \& Starešinić, 2016). Active or passive participation in sports is a frequent motivation for traveling to tourist destinations (Perić, Čuić Tanković \& Đurkin, 2017). Sport and tourism are intrinsically connected, so as globalization progresses technologically, through telecommunications and traffic, new exciting opportunities open up for enriching the tourist experience through sports, as well as for accelerating sports development through tourism (De Knop \& Van Hoecke, 2003).

The promotion of the state through sports is a very important factor of every country, not only Bosnia and Herzegovina. Some athletes earn more than doctors who save lives. Through various sporting events, attempts are made to contribute to the development of a particular country, which has been successful so far (Janković, 2016). The purpose of this paper will be based on how sport and professional athletes promote their own country through their activities.

Bosnia and Herzegovina's image has long been tarnished by the war, but also by the unstable political situation in the country. However, more and more tourists are visiting Bosnia and Herzegovina (Čaušević, Mirić, Drešković \& Hrelja, 2020), and it can be concluded that the image of the country in the minds of tourists is ${ }^{1}$ much better and more favorable (Čausević, 2019). Recent research has shown that the image of the capital, Sarajevo, but also of Bosnia and Herzegovina in general, is positive (Čaušević \& Čizmić 2017; Čaušević, 2019; Čaušević, Mirić, Drešković \& Hrelja, 2019).

The role of professional athletes in creating the image of Bosnia and Herzegovina has not yet been explored. Bosnia and Herzegovina has great sports potential, which can help it in the development of tourism. Athletes as public figures have a great influence on the youth and the general public, and as such can use their influence for promotional purposes.

The purpose of this paper is to present the current perception of Bosnia and Herzegovina on the global market, the contribution of sports professionals in creating the image of Bosnia and Herzegovina, as well as the potential and future of sports tourism in Bosnia and Herzegovina. This topic has not been sufficiently researched, and this research will fill the gaps in the existing literature. A qualitative research method was used, which showed that Bosnia and Herzegovina has a lot of untapped sports potential, mostly in winter sports; that the most lucrative sport is football, and that Edin Džeko is the most influential person in Bosnian sports.

This contribution of this paper is in summarizing the current knowledge about sports tourism, and points out how Bosnia and Herzegovina should improve its image through sports, sports tourism and through investments in professional athletes.

\section{METHODOLOGY AND RESEARCH RESULTS}

A qualitative method was used in the research. The qualitative method was conducted with six experts in the field of sports, in the form of in-depth interviews. The aim of the research is to find out and analyze the views of experts in the field of sports, sports journalism and on the topic of sports tourism and its impact on the image of Bosnia and 
Herzegovina through the promotion of professional athletes. An in-depth interview was conducted with six experts, namely a football coach, a professional athlete in the field of football, two sports journalists, a PR manager of a football club from Bosnia and Herzegovina and a former PR manager of football club from Bosnia and Herzegovina. The questions asked were as follows: Do athletes in $\mathrm{BiH}$ have an impact on the public and youth and in what way (Do you have a specific example of an athlete)? How much more popular is sport today than ten years ago and how (in terms of attendance at sports events, readership of sports portals, number of sports news, views, etc.)? How much does the rating of the sport increase after an event (Do you have an example)? What is a sports ambassador for you? Does sports tourism in $\mathrm{BiH}$ have a future and how? Who do you think is the most influential $\mathrm{BiH}$ athlete and why, and have there been any changes in $\mathrm{BiH}$ sports or tourism since their success? What is the most lucrative sport in $\mathrm{BiH}$ and where does it have the most potential and opportunities for development? When was the greatest flourishing of $\mathrm{BiH}$ sports and is sport progressing in $\mathrm{BiH}$ ? Does $\mathrm{BiH}$ have the capacity and possibilities to organize a major sporting event? How can sport be used for tourism purposes and how can $\mathrm{BiH}$ athletes help create a more positive image of $\mathrm{BiH}$ as a tourist destination?

According to the player of the football club Željezničar from Sarajevo, Aleksandar Kosorić, athletes have less and less influence on the youth and unfortunately other people are role models for the youth, except for big stars, i.e athletes, such as Džeko, Tuka, Ronaldo, Messi. Young people follow them and try to impersonate them in some manner, behavior and appearance. According to Amar Osim, the coach of the football club Željezničar, the only athlete with an impact on the youth is Edin Džeko. Former PR manager of the football club Željezničar, Emir Muhamedagić, believes that athletes certainly have a great influence on society and the people. This is especially true for children and young people to whom Bosnian athletes are role models. He also believes that citizens perceive the successes of athletes as their own and the successes of the state of Bosnia and Herzegovina, which significantly contributes to the overall atmosphere in society.

Public relations expert of the football club Željezničar from Sarajevo, Armin Herić, believes that $\mathrm{BiH}$ athletes have an impact on the public. He thinks that the most popular athletes send a message to the public with their socially responsible work, and this especially affects the youth who see their idols in them. He primarily thinks of athletes such as Edin Džeko, Amel Tuka, Mirza Teletović or Damir Džumhur. According to him, young people see an opportunity in sports and the public must understand, as soon as possible, that sport is one of the best ambassadors, but also one of the best ways of development for young people.

Sports journalist and journalist of the news portal Klix.ba, Nermin Kustura, believes that successful athletes can be a role model for young people the most. He thinks that athletes, by setting good example, can serve to reach the greatest heights with good and patient work. There are many examples; some of them are Džeko, Pjanić, Nurkić, Tuka. Adnan Pločo, editor of the news portal Sportske.ba, also thinks that athletes have an influence, because, for years, athletes have been the greatest role models for young people. For him, the best example is Edin Džeko, because, in his opinion, that all boys who play football dream of having his career. On the other hand, Džeko is a great humanitarian, an ambassador of UNICEF, someone who is really a person for example and he is a role model for many young people. 
Kosorić believes that sports are very different today and 10-15 years ago. According to him, today's sport is more popular, there is much more money in sports, which in turn leads to much greater representation in the media, among sponsors, people who follow certain sports and in society in general. Amar Osim doesn't think the sport is more popular today than it was 10 years ago. Muhamedagić is of the same opinion; he thinks that sport is definitely more accessible today due to the technological development of the market. By this, he primarily thinks of the possibilities that the Internet and cable television offer, so that from the comfort of your own home, you can follow any sport at any time.

Herić believes that perhaps only tennis is more popular in Bosnia and Herzegovina today than ten years ago, primarily because of Damir Džumhur. He thinks other sports are either stagnant or declining in popularity. Although today information is much more accessible to the public through portals and other media, certain sports, due to lack of quality and finances, are not at the level they can and should be. According to Kustura, sport is much more popular today due to its easy accessibility. Stadiums around the world are constantly being renovated and expanded, which is a clear sign that the audience is growing. Also, an increasing number of companies want to promote themselves through sports because they know that they can reach a wide range of clients so easily.

Pločeo believes that sport is more popular today only because there are more media, which make things more accessible to the public than ten years ago. The media have brought sport closer to the wider masses, although the big problem of today's society is that it is often reported subjectively, sometimes you just "run" for a click, you do not look at the basic postulates of journalism. Sport is more popular today than ten years ago, not because of some big difference in the quality of athletes, but because there is now a lot more money in sports, marketing is more interesting and events are more accessible than before.

Due to the mentality of Bosnia and Herzegovina, a sports event is considered successful only when victory is achieved, believes Herić. We can see an example in the Bosnian national football team; when they achieve good results, a huge euphoria is created and the state literally lives for those matches and victories. So, the ratings increase in case of success. Apart from that, he believes that the ratings of sports used to increase after a sports event, but this is no longer the case, because now all sports are available at all times and there is no longer that effect as there used to be. Pločo believes that the ratings increase after the sports event. There are many examples, for example the games of the Handball Club Bosna in the EHF Cup, when they managed to reach the semifinals and the "Mirza Delibašić" hall was always filled to the last place. Good results are the key to great attendance and interest. After the good results of Damir Džumhur at the ATP tournaments two seasons ago, the number of boys and girls who started playing tennis increased significantly, and the media became more interested in his games. A similar example is Amel Tuka. Five or six years ago, almost no one knew him, and today, after great results, the whole world knows about him, and in Bosnia and Herzegovina he is the idol of many.

Kustura thinks that the viewership will increase, if the event is successful. Kusutra gave an example of a KSW event in Zagreb, which he attended. It's an MMA sport. There were 15,000 spectators in the hall and after such a successful event it is clear that they 
practically "bought" those 15,000 Croatian fans of this fastest growing sport in the world, which is an example of how much impact the sporting event has on the development of sports.

The opinions about the sports ambassador in most cases coincide. According to Kosorić, a sports ambassador is a person who is a "complete" person in every respect, a person who will be a role model to other people in every segment of his life, an example of a true athlete in all possible fields and thus an example and image of society and state in representing Bosnia and Herzegovina abroad. According to Osim, a sports ambassador is someone who promotes true values through his activities in the sports field, but especially outside of it. A sports ambassador is a person who, by his own actions on and off the field, gives an example, primarily to young people, of how an athlete should behave. Also, Muhamedagić believes that sports ambassadors are people who, with their own credibility, can give significant support to certain activities and campaigns aimed at concrete changes in society. The sports ambassador is a person of great popularity in his country, and, according to Herić, achieves his success all over the world. In this way he presents his homeland. A small flag next to the name on TV screens is a huge thing for the country and state institutions at all levels should start investing in sports as soon as possible. For Pločo, the sports ambassador is someone who makes good results on sports arenas, and outside of them has no stains in private life, they are socially responsible, engaged in humanitarian work, tries to help those in need with his stellar status and represents the country they comes from in the best manner possible. Edin Džeko's example should be the one that all athletes from Bosnia and Herzegovina should follow. For Kustura, the sports ambassador is the person who presents the country in the best way. Because of them, a large number of people find out about the country from which the athlete comes. That is why they say that athletes are the best ambassadors.

Bosnia and Herzegovina has excellent potentials for sports tourism, has mountains on which to build sports centers and with which it could certainly attract many foreign athletes. There is also one example of a sports center in Medjugorje, which is on a par with many foreign ones where Bosnian teams and athletes are staying and preparing. Kosorić's conclusion is that Bosnia and Herzegovina has a huge untapped potential for sports tourism. Amar Osim believes that Bosnia has a good climate in summer and Herzegovina a good climate in winter, which is a basic prerequisite for the development of sports tourism. The main drawback is, the lack of money that should be invested in infrastructure. Pločo thinks that there is no potential, because in general, Bosnian sport has fallen on hard times, there are no significant successes, nor any "legends" of world sports that would be interesting to people and attract them to $\mathrm{BiH}$. The greatest success of Bosnia and Herzegovina is still the 1984 Olympic Games, and $\mathrm{BiH}$ has never known and still does not know how to use it in the best possible way.

Heric believes that the current stepmotherly relationship of state institutions does not bring any healthy future to Bosnian sports. Former European champion, BC Bosna, is in bankruptcy, several football clubs have huge financial problems due to the fact that there is no law on sports, and the national handball team financed the attendance at the European Championship exclusively from donations from friends of sports. It is a disgrace for the state that sports tourism has no future in the current situation. Kustura believes that sports tourism has a pale future, and gives the Olympic mountains as an example; there is a lot of potential, but are so poorly invested that they are simply overlooked. 
Given all the potentials that Bosnia and Herzegovina has, sports tourism is certainly a segment that has potential. These primarily include sports that are related to the geographical potential of the country, and in this context, these are winter sports, as well as extreme sports: mountaineering, mountain biking, paragliding, rafting, and free climbing. Half marathons in Sarajevo and Banja Luka, triathlon in Konjic, traditional and Red Bull Cliff Diving jumps in Mostar are the best examples. Muhamedagić believes that it is difficult to assess empirically who is the most influential athlete in Bosnia and Herzegovina. According to him, there are several of them, some being Edin Džeko, Miralem Pjanić, Amel Tuka, Damir Džumhur, Mirza Teletović. According to Amar Osim, the most influential of them is Edin Džeko and he thinks that nothing significant happened after his success, except that the parents became more ambitious in coaching their children, because everyone's desire for a potential new Džeko was awakened. According to Herić, Edin Džeko is someone who should be written in golden letters in BiH sports. He sent a message to all the boys on the street that with quality work they can make their dreams come true.

The most influential BiH athlete is Edin Džeko. The changes after his success are not visible, but his name is the first association to Bosnia and Herzegovina, not including the war. Pločo claims that people in the world know about Džeko, and they don't really know anything about the country he comes from. He had a personal experience when a person asked him where he was from and, when he answered, told him he knows about Džeko, but nothing else about $\mathrm{BiH}$. Kusutura also agrees that Džeko is the most influential athlete, because of his phenomenal club career, but also because of his contribution to the $\mathrm{BiH}$ national team. Also, there is his humanitarian work. He thinks that a large number of boys started training because of him, but that he did not have much of an impact on tourism.

Kosoric believes that football is the highest paid today, and therefore it is the most lucrative sport. Bosnia and Herzegovina is a country of sports because it has a lot of potential in all sports, but it has very poor conditions and is very late in development for some world trends, such as, above all, the training of coaches in all sports. Apart from that, he believes that the most potential lies in indoor sports (basketball, handball). The infrastructure (halls) existing in $\mathrm{BiH}$ can be used throughout the year.

According to Muhamedagić, the most lucrative sport is definitely football, but it is probably the most expensive in terms of organization and the necessary resources to achieve a result. Each sport has its own specifics, both financial and organizational, and it is difficult to assess which has the greatest potential for development. Herić believes that football is a sport with the most potential in Bosnia and Herzegovina. With even small investments from state institutions, Bosnian clubs can achieve much better success in European competitions. The money that is "distributed" in European competitions is huge and he thinks that it is direct foreign capital that enters the country. Pločo believes that the most lucrative sport is certainly football, because it is the most followed by the media, the most money is spent and that is the easiest way for an athlete to make a career abroad. He thinks that there is potential in winter sports, but that not even $1 \%$ has been used. Kustura also thinks football has proven to be the most lucrative. However, greater progress requires better work in the youth categories and far better infrastructure. Handball also has potential, as it is very popular in almost all smaller communities. 
According to Muhamedagić, the flourishing of sports in Bosnia and Herzegovina did not happen, and the successes and results of Bosnia and Herzegovina can hardly be described as prosperous. But according to him, the pinnacle of Bosnian sports is winning the first Olympic medal, and he hopes that Larisa Cerić or Amel Tuka will succeed in that this year. Sport in $\mathrm{BiH}$ is not progressing. It lives solely on the enthusiasm of people and the successes of individuals who are more incidents and the fruit of their own work than some systemic support. Apart from that, he has a similar attitude, and believes that there is hardly any progress. For him, the biggest success is the placement of the Bosnian national football team at the 2014 World Cup.

Heric believes that the biggest boom of $\mathrm{BiH}$ sports is the placement of the national football team at the World Cup in Brazil. All clubs recorded an increase in the number of trainees in youth schools, which is a very good example of the flourishing of sports. Sport in $\mathrm{BiH}$ is not progressing due to low level of investments. Every success of a sport in Bosnia and Herzegovina at international competitions brings a certain flourishing, but unfortunately it is short-lived, because Bosnia and Herzegovina as a nation forgets all great successes very quickly. Progress in $\mathrm{BiH}$ sports has been very slow and more and more behind many countries in the world, ahead of which Bosnia and Herzegovina has been for years, Kosorić said. The biggest boom, according to Pločo, was after the placement of the national football team at the World Cup, but in general, $\mathrm{BiH}$ sport is falling behind and there is no progress. Kustura is of the same opinion that the biggest boom was in 2014, when the $\mathrm{BiH}$ national football team played at the World Cup. It was all everyone walked about. The sport is progressing, but in extremely small steps. This is especially true of club sports, while the national team somehow copes with other selections.

As for the organization of some sports events, Kosoric thinks that Bosnia and Herzegovina has the capacity to organize larger sports events for winter sports such as skiing and some individual ones such as judo, kick boxing and the like. Apart from that, he believes that there are several fair halls in Bosnia and Herzegovina and that a championship in some less demanding sports could be organized.

Muhamedagić is skeptical, and thinks that at this moment there is no financial, infrastructural or human capacity to organize a bigger sports competition. Herić believes that there is certainly the capacity to organize a sports event. He sees no reason why the surrounding countries can do that, and $\mathrm{BiH}$ cannot. This requires a much better approach and a much better desire of the state for the development of sports. The City of Zagreb invests several million euros in GNK Dinamo Zagreb alone, while the Sarajevo Canton, which has a budget of almost a billion KM, allocates only fifteen million KM to sports. The previously organized EYOF showed that $\mathrm{BiH}$ can organize a sports event. However, the catastrophic infrastructure does not give much hope for Kustura.

Kosoric thinks that sports could be used for the purpose of tourism, and $\mathrm{BiH}$ athletes could help raise the awareness of $\mathrm{BiH}$ as a tourist destination. Osim believes that we should try to attract top foreign athletes or teams to some preparations in Bosnia through private connections. Athletes themselves are not able to help without the huge support of the state in the first place, then sponsors and the media. Everything needs to fall into place with the best athletes at the top and then there would be a huge impact on raising awareness among all citizens. Sport is the best ambassador of a country. Thanks to the success of Bosnian athletes, many people around the world have heard of $\mathrm{BiH}$ for the 
first time. The best example of the use of athletes for the purpose of promoting tourism is the campaign organized by the Croatian Tourist Board. Among other celebrities, Croatian footballers, such as Luka Modrić, Ivan Rakitić, Mario Mandžukić, Mateo Kovačić, Dejan Lovren, appear in the promotional video. The promotional video is available at https://www.youtube.com/watch?v=xvBEW-aLGSs. BiH must raise better athletes who will record successes in the world and thus tell the story of $\mathrm{BiH}$. In this way, people around the world will get to know $\mathrm{BiH}$, which has a lot to offer, from nature, history, architecture and so on. The key is in quality work and the creation of new Džeko, Teletović, Džumhur, concludes Herić. The organization of large sporting events would also attract a large number of tourists. On the other hand, Kustura believes that athletes alone cannot do anything more on a global scale.

\section{CONCLUSION}

According to the conducted in-depth interviews with public figures from the world of sports, it can be concluded that the opinions of experts are very similar to almost all questions. Most respondents agree that athletes in general have an impact on youth, as their role models and idols, and that the greatest role model for young people in Bosnia and Herzegovina is football player Edin Džeko. Sport is more popular today in the sense that it is more accessible because the media are more widespread today, so information is much more accessible than it was ten years ago. Also, today in sports, in the game, there is much more money and investment, and sport is therefore a good investment, so it is more popular globally because of sponsorship, promotion and marketing. In essence, the quality of sports has not improved, but with the globalization and the emergence of social networks, the viewership of sports has increased, so it is only in that sense that it is more popular. As for Bosnia and Herzegovina, most respondents are of the opinion that sports in $\mathrm{BiH}$ are stagnating and that only the popularity of tennis has increased, at the expense of the short popularity of tennis player Damir Džumhur. However, the fact is that in Bosnia and Herzegovina, more is being invested in the construction of stadiums, reconstruction, and it can be said that the potential of the sport has been recognized, and its possibilities have begun to be used.

When it comes to increasing viewership after a sporting event, opinions are divided. One part believes that the viewership is increasing, and that there are concrete examples of that, such as the success of Damir Džumhur, in tennis competitions, where the interest in following this sport automatically increased, or the success of handball ten years ago, when the handball club Bosna from Sarajevo, experienced European successes and filled the halls. However, there is another side, which thinks that the viewership increases only if the event is successful, especially in Bosnia and Herzegovina, where the mentality is such that the euphoria after the victory is created in the short term and disappears quickly.

All respondents agreed that a sports ambassador is someone who sets an example to young people with his behavior, on and off the field. It is a person who is socially responsible, participates in humanitarian activities and acts outside sports fields with his behavior. They agreed that the most ideal example is the sports ambassador of Bosnia and Herzegovina, Edin Džeko. The conclusion is that Bosnia and Herzegovina has the potential for sports tourism, mostly through winter sports and the Olympic mountains. However, everyone is of the opinion that this potential has not been used, that $\mathrm{BiH}$ has 
a pale future in sports tourism, that there is no investment in infrastructure and that there is not enough investment in sports. In essence, the state should take concrete measures for the potential that is available, and start allocating a larger budget for sports tourism, which, according to the current trend, is declining and has no signs of improvement.

All respondents agreed that Edin Džeko is the most influential athlete in $\mathrm{BiH}$, but that after his success, nothing significant has changed, except that there is a greater interest of children to play football. The conclusion is that the most lucrative sport is football, but that in Bosnia and Herzegovina, apart from football, it has the most potential for the development of winter sports, as well as indoor or team sports (handball). Most agree that the greatest success of Bosnia and Herzegovina is the placement at the World Cup in football in 2014, and Muhamedagić also cites the example of Amel Tuka, who was the first to bring a medal from a major competition. They are also of the opinion that sport in $\mathrm{BiH}$ is not progressing and that it is lagging behind Europe.

Opinions are divided on the organization of a major sports event in $\mathrm{BiH}$. Some think there is no capacity, no infrastructure, no money for such a thing, while some think there is a possibility, and that EYOF is an example that it is possible. Regarding the use of sports for tourism purposes, the conclusion is that it is necessary to invest in sports events so that people hear about Bosnia and Herzegovina, invest in athletes so that they can make bigger and better results, and thus promote $\mathrm{BiH}$, and that athletes themselves cannot do more without the help of the state, sponsors and the media.

Although this research provided a lot of information, there were a few limitations that did not affect the goal of the research. The first limitation is the fact that a qualitative method was used in the research, and that in-depth interviews as a research method may be unrepresentative in relation to the entire population. Also the findings from the answers may be subjective and not entirely relevant to the research. The limitation is certainly the problem of finding an adequate person for an in-depth interview, as well as the fact that the respondent must have a basic knowledge of the given topic.

The recommendation for further research is to conduct quantitative research as well. After this research, it was concluded that it is very difficult to analyze the role of professional athletes in the development of sports tourism in Bosnia and Herzegovina. Qualitative research can hardly meet such a requirement and therefore a quantitative approach is needed.

\section{LITERATURE}

1. Bartoluci, M. (1985). Ocjena ekonomskih efekata sportske rekreacije u turizmu s posebnim osvrtom na Jadranski turizam Jugoslavije. Doctoral dissertation, Zagreb: Faculty of Economics \& Business University of Zagreb.

2. Bartoluci, M. (1995). Role of sport and recreation in the development of Croatian tourism. Tourism and hospitality management, 1(2), 253-265.

3. Bartoluci, M,. Škorić, S., \& Starešinić, Z. (2016). Sports tourism offer in Croatia. Poslovna izvrsnost Zagreb, 10(2), 9-26.

4. Čaušević, A. (2019). Razvoj medicinskog turizma u Bosni i Hercegovini. Pregled, 60(3), 125-138. 
5. Čaušević, A. (2019). Analysis of the image of the City of Sarajevo. Geografski pregled, 41, 87-96.

6. Čaušević, A. \& Čizmić, E. (2017). Uticaj specifične manifestacije na percepciju turističke destinacije - Primjer Sarajevo Film Festivala. Sarajevo Business \& Economics Review (Zbornik Radova), 35, 30-50.

7. Čaušević, A., Mirić, R., Drešković, N. \& Hrelja, E. (2019). Cognitive Image of a Tourism Destination: the Case of Sarajevo. African Journal of Hospitality, Tourism and Leisure, 8(2), 1-12.

8. Čaušević, A., Mirić, R., Drešković, N. \& Hrelja, E. (2020). First-time and repeat visitors to Sarajevo. European Journal of Tourism, Hospitality and Recreation, 10(1), 14-27.

9. De Knop, P. \& Van Hoecke, J. (2003). Uloga sporta u borbi za turiste: figuralna perspektiva razvoja sportskog turizma. Kinesiology, 35(1), 59-71.

10. Higham, J. \& Hinch, T. (2001). Sport tourism: A framework for research. International Journal of Tourism Research, 3, 45-58.

11. Janković, Lj. (2016). Promocija Republike Hrvatske kroz sport na internetu. Bachelor thesis, Pula: Fakultet ekonomije i turizma "Dr. Mijo Mirković Sveučilište Jurja Dobrile u Puli.

12. Kesar, O. (2007). Special interest tourism as a catalyst for sustainable destination development. In M. Bartoluci, N. Čavlek, and associates, Tourism and Sport Aspects of Development (pp. 290-296). Zagreb: Školska knjiga.

13. Perić, M., Čuić Tanković, A. \& Đurkin, J. (2017). Role of brand personality traits in creating an umbrella brand for small-scale sports events: The case of Gorski Kotar, Croatia. DRUŠ. ISTRAŽ. ZAGREB, 26(4), 561-581.

14. Škorić, S. (2008). Sportski turizam i njegovi učinci na turističke destinacije Primjer Istre. Acta turistica, 20(1), 69-92. 